\title{
RENCANA PERBAIKAN PEMBELAJARAN MATA PELAJARAN ILMU ILMU PENGETAHUAN SOSIAL MENGGUNAKAN METODE DEMONSTRASI DAN MEDIA AUDIOVISUAL UNTUK MENINGKATKAN MINAT, MOTIVASI DAN PEMAHAMAN SISWA
}

\author{
Dede Rusmiati \\ Dederusmiati057@Gmail.Com
}

\begin{abstract}
This study discusses the use of demonstration methods and audiovisual media in the study of Social Sciences. This study is motivated by the low learning outcomes of many factors, especially the factors of teachers and students. The teacher as an important component in the teaching and learning process has a very strategic role in the effort to establish quality human resources. The low learning outcomes of social studies are following several studies. Thus, learning using demonstration methods with audiovisual media can improve learning outcomes, activeness, and motivation for students. The responsibility of students towards the task is quite high and helps students to be actively involved in learning activities.
\end{abstract}

Keywords: demonstration, audiovisual, and IPS

\section{PENDAHULUAN}

Kegiatan pembelajaran di jenjang SD secara umum haruslah bersifat konkret, berdasarkan hal tersebut pada pembelajaran IPS guru sebagai pendidik harus mampu memberikan pembelajaran kepada peserta didik yang konkret (nyata) serta menarik yakni menggunakan metode mengajar yang sesuai dengan materi pelajaran yang diterima peserta didik. Selain itu, guru juga harus menggunakan alat peraga atau media pembelajaran agar peserta didik dapat mencerna pembelajaran tersebut. Sehingga pembelajaran dapat dilakukan secara maksimal dan nilai hasil belajar yang diraih peserta didik pun tinggi [1]

Tujuan pembelajaran IPS adalah untuk memberikan pengetahuan dan kemampuan kepada peserta didik untuk mengenal gejala dan masalah sosial di masyarakat dengan meninjau dari berbagai aspek kehidupan atau satu perpaduan seperti kenampakan alam, sumber daya alam, potensi alam, dan lain sebagainya. Untuk itu, tidaklah mudah mencapai keberhasilan kegiatan 
pembelajaran peserta didik tanpa adanya krestifitas dan inovasi kegiatan pembelajaran dari guru [2]

Rendahnya hasil belajar tersebut banyak faktor terutama faktor guru dan peserta didik. Guru sebagai komponen penting dalam proses belajar mengajar mempunyai peran yang sangat strategis dalam usaha pembentukan sumber daya manusia berkualitas. Rendahnya hasil belajar IPS sesuai dengan beberapa penelitian, seperti penelitian Damanhuri.dkk dan penelitinya Sulfemi dan Nurhasanah. Selanjutnya penelitian dari Windiyani dkk. yang berjudul "Penggunaan Media Pembelajaran Gambar Fotografi Pada Mata Pelajaran Ilmu Pengetahuan Sosial Siswa Sekolah Dasar" bahwa belajar IPS dari 30 orang siswa kelas $\mathrm{V}$ perolehan nilai yang di atas Kriterian Ketuntasan Maksimal hanya 10 orang siswa atau 33,3\% yang dinyatakan sudah mencapai sedangkan 20 orang siswa atau $66,7 \%$ belum mencapai. [3], [4]. [5].

Keadaan seperti di atas perlu dilakukan suatu tindakan yang dapat menyelesaikan permasalahan dalam proses pembelajaran di kelas terutama dalam pembelajaran IPS [6] materi kenampakan alam. Dalam menyikapi permasalahan ini peneliti mencoba menggunakan metode demonstrasi dan media pembelajaran audio visual. Metode demonstrasi digunakan peneliti untuk menunjukkan secara langsung kepada peserta didik bentuk-bentuk kenampakan alam, tujuannya mengonkretkan contoh yang abstrak yang diberikan oleh guru. Hal tersebut dilengkapi dengan media audio visual agar peserta didik lebih tertarik dalam kegiatan pembelajaran dan lebih mudah memahami apa yang dimaksud oleh guru seperti contoh kenampakan alam perairan antara lain sungai, danau, rawa, laut, dan selat serta kenampakan alam daratan diantaranya adalah pantai, dataran rendah, dataran tinggi, lembah, gunung, dan pegunungan.

Setelah latar belakang masalah di uraian seperti di atas, maka perlu kajian agar materi pembelajaran Mata Pelajaran Ilmu Pengetahuan Sosial Materi Kenampakan Alam dapat diterima peserta didik agar dapat Meningkatkan Hasil Belajarnya

\section{METOLOGI}


Penelitian ini menggunakan pendekatan kualitatif, yaitu dengan menekankan analisisnya pada proses penyimpulan komparasi serta pada analisis terhadap dinamika hubungan fenomena yang diamati dengan menggunakan logika ilmiah. Penelitian kualitatif merupakan pendekatan yang menghasilkan data deskriptif berupa kata-kata tertulis dari orang-orang yang diamati yang tidak dituangkan ke dalam istilah yang digunakan dalam penelitian kuantitatif [7]

Dalam penelitian ini digunakan riset kepustakaan. Penelitihan pustaka atau riset pustaka ialah serangkaian kegiatan yang berkenaan dengan metode pengumpulan data pustaka, membaca dan mencatat serta mengolah bahan koleksi perpustakaan saja tanpa memerlukan riset lapangan [8]

Penelitian ini akan menampilkan argumentasi penalaran keilmuan dari hasil kajian pustaka dan hasil olah pikir peneliti mengenai suatu masalah atau topik kajian. Jenis penelitian ini didukung oleh data yang diperoleh dari sumber pustaka yang berupa jurnal penelitian, skripsi, laporan penelitian, buku teks, makalah, laporan seminar, diskusi ilmiah, dan lain sebagainya. Bahan-bahan pustaka tersebut dibahas secara kritis dan mendalam dalam rangka mendukung pembahasan yaitu penggunaan metode demonstrasi dan media audiovisual dalam pembelajaran Ilmu Pengetahuan Sosial

Teknik Pengumpulan Data dalam penulis hasil karya tulis ini berupa buku dan jurnal, kemudian membaca dan mencatat bahan-bahan yang diperlukan untuk memperoleh informasi yang bekaitan dengan pembahasan

\section{PEMBAHASAN}

\section{Hasil Belajar IPS}

Menurut Anitah Pembelajaran adalah proses interaksi peserta didik dengan pendidik dan sumber belajar pada suatu lingkungan belajar. Lingkungan belajar merupakan suatu sistem yang terdiri dari unsur tujuan, bahan pelajaran, strategi, alat, peserta didik, dan guru. Semua unsur atau komponen tersebut saling berkaitan, saling mempengaruhi, dan semuanya berfungsi dengan berorientasi pada tujuan. Oleh karena itu, media yang digunakan sebagai alat 
dalam pembelajaran sangatlah penting untuk mencapai hasil belajar yang maksimal [9]

Kemudian Hamalik dan Sulfemi menyatakan, bahwa hasil belajar adalah apabila seseorang telah belajar akan mengalami perubahan tingkah laku pada orang tersebut. Dari tidak tahu menjadi tahu, dari tidak bisa menjadi bisa, dan sebagainya. Tingkah laku manusia terdiri dari sejumlah aspek hasil belajar akan tampak pada setiap perubahan pada aspek-aspek: pengetahuan, emosional, pengertian, hubungan sosial, kebiasaan, jasmani, keterampilan, etis atau budi pekerti, apresiasi, dan sikap [10] [11]

Selanjutnya masih menurut Sulfemi menyatakan, hasil belajar adalah pola-pola perubahan, nilai-nilai, pengertian-pengertian, sikap-sikap, apresiasi dan keterampilan yang diterima oleh peserta didik apabila menerima kepuasan pada kebutuhannya dan berguna, serta bermakna baginya.[12]

Kemampuan yang dimiliki peserta didik dari proses pembelajaran harus mendapatkan hasil, bisa melalui kreatifitas seseorang atau tanpa adanya intervensi orang lain [13]. Menurut Sudjana hasil belajar adalah kemampuankemampuan yang dimiliki peserta didik setelah menerima pengalaman belajarnya . Sedangkan menurut Horwart Kingsley dalam bukunya Sudjana (2014: 22) membagi tiga yaitu: (1) Keterampilan dan kebiasaan, (2) Pengetahuan dan pengarahan, (3) Sikap dan cita-cita. [14]

Perolehan hasil belajar peserta didik sangat erat kaitannya dengan tujuan pembelajaran yang direncanakan oleh guru. Menurut Gagne yang dikutip Sulfemi mengemukakan lima kategori hasil belajar, antara lain: (1) informasi verbal, (2) keterampilan intelektual, (3) strategi kognitif, (4) sikap, (5) keterampilan motoris [15]

Dengan demikian penulis sampaikan, bahwa hasil belajar merupakan setelah proses interaksi belajar terjadi, peserta didik akan mengalami perubahan tingkah laku dan mendapat hal yang bermakna baginya yang mencakup berbagai kategori, yaitu : informasi verbal, keterampilan intelektual, strategi kognitif, sikap, dan keterampilan motoris.

Menurut Sardiyo IPS, seperti halnya IPA, Matematika, dan Bahasa Indonesia merupakan bidang studi. Dengan demikian, IPS sebagai bidang studi 
memiliki garapan yang dipelajari cukup luas. Bidang garapannya itu meliputi gejala-gejala dan masalah kehidupan manusia di masyarakat. Tekanan yang dipelajari IPS berkenaan dengan gejala dan masalah kehidupan masyarakat bukan pada teori dan keilmuannnya, melainkan pada kenyataan kehidupan kemasyarakatan. Dari gejala dan masalah sosial tadi ditelaah, dianalisis faktorfaktornya sehingga dapat dirumuskan jalan pemecahannya. Memperhatikan kerangka kerja IPS seperti yang dikemukakan di atas dapat ditarik pengertian IPS sebagai berikut. IPS adalah bidang studi yang mempelajari, menelaah, menganalisis gejala dan masalah sosial di masyarakat dengan meninjau dari berbagai aspek kehidupan atau satu perpaduan [16].[17]

Sedangkan menurut Udin dalam Ahmadi social studies atau Ilmu Pengetahuan Sosial adalah ilmu-ilmu sosial yang disederhanakan untuk tujuantujuan pendidikan dan pengajaran di sekolah dasar dan menengah. Dengan begitu, dapat disimpulkan Ilmu Pengetahuan Sosial (IPS) ialah ilmu-ilmu sosial yang dipilih dan disesuaikan bagi penggunaan program pendidikan di sekolah atau bagi kelompok belajar lainnya, yang sederajat. Materi dari berbagai disiplin ilmu sosial seperti Geografi, Sejarah, Sosiologi, Antropologi, Psikologi Sosial, Ekonomi, Ilmu Politik, Ilmu Hukum dan ilmu-ilmu sosial lainnya, dijadikan bahan baku bagi pelaksanaan program pendidikan dan pengajaran di sekolah dasar dan menengah. Ilmu Pengetahuan Sosial (IPS) adalah bidang studi yang merupakan panduan (fusi) dari sejumlah mata pelajaran sosial.[18]. [19]

Kemudian Ahmadi (2009: 3) menyatakan, ilmu-ilmu sosial merupakan dasar dari IPS. Akan tetapi perlu dicamkan bahwa tidak semua ilmu-ilmu sosial secara otomatis dapat menjadi bahan/pokok bahasan dalam IPS. Tingkat usia, jenjang pendidikan dan perkembangan pengetahuan peserta didik, sangat menentukan materi-materi ilmu-ilmu sosial mana yang tepat menjadi bahan/pokok bahasan dalam IPS. Di Indonesia IPS menjadi salah satu mata pelajaran dalam pembaruan kurikulum SD, SMP dan SMA dalam kurun waktu 1975-1976, dan masih berlangsung hingga sekarang ini [18]

Dengan demikian penulis dapat simpulkan IPS adalah ilmu pengetahuan tentang manusia dalam lingkungan hidupnya. Lingkungan hidup yang dimaksud adalah yang mempelajari kegiatan hidup manusia dalam kelompok 
masyarakat dengan menggunakan berbagai disiplin ilmu sosial, seperti sosiologi, geografi, ekonomi, sejarah, antropologi, dan sebagainya.

Kemudian penulis menyimpulkan hakekat hasil belajar IPS adalah perubahan perilaku peserta didik baik kategori informasi verbal, keterampilan intelektual, strategi kognitif, sikap, maupun keterampilan motoris, setelah proses interaksi belajar terjadi, dengan kecepatan dan ketepatan dalam mengaplikasikan di berbagai disiplin ilmu sosial seperti sosiologi, geografi, ekonomi, sejarah, antropologi, dan sebagainya.

\section{Metode Demonstrasi}

Metode pembelajaran adalah cara yang digunakan oleh guru dalam melaksanakan kegiatan belajar mengajar di kelas sebagai upaya untuk mencapai tujuan pembelajaran yang telah ditetapkan [20]. Teori tersebut didukung oleh Djamarah metode adalah strategi yang tidak bisa ditinggalkan dalam proses belajar mengajar. Setiap kali mengajar guru pasti menggunakan metode. Metode dipergunakan tidak sembarangan, melainkan sesuai dengan tujuan pembelajaran. Setiap tujuan yang dirumuskan menghendaki penggunaan metode yang sesuai. Untuk mencapai suatu tujuan tidak mesti menggunakan satu metode, tetapi bisa juga menggunakan lebih dari satu metode. Apa lagi bila rumusan tujuan itu lebih dari dua rumusan tujuan. Dalam hal ini diperlukan penggabungan penggunaan metode mengajar. Dengan begitu kekurangan metode yang satu dapat ditutupi oleh kelebihan metode yang lain. Strategi metode mengajar yang saling melengkapi ini akan menghasilkan hasil pengajaran yang lebih baik daripada penggunaan satu metode. [21]

Kemudian selanjutnya Djamarah melanjutkan hakikat penggunaan metode mengajar yang bervariasi dapat menjembatani gaya-gaya belajar peserta didik dalam menyerap bahan pelajaran. Umpan balik dari peserta didik akan bangkit sejalan dengan penggunaan metode mengajar yang sesuai dengan kondisi psikologis peserta didik. Maka penting memahami kondisi psikologis peserta didik sebelum menggunakan metode mengajar guna mendapatkan umpan balik optimal dari setiap peserta didik. [21]

Sedangkan menurut Nurhayati metode pembelajaran adalah cara yang dipergunakan untuk mencapai tujuan yang telah ditetapkan (RPP) secara 
sistematis. Seorang pengajar tidak dapat memberikan pembelajaran dengan baik apabila tidak menguasai metode secara tepat. Lima faktor yang mempengaruhi antara lain: (1) Tujuan dengan berbagai jenis dan fungsinya. (2) Anak didik dengan berbagai tingkat kematangan. (3) Situasi berlainan keadaannya. (4) Fasilitas bervariasi secara kualitas dan kuantitas. (5) Kepribadian dan kompetensi guru yang berbeda beda [22]

Berdasarkan uraian di atas, disimpulkan bahwa metode pembelajaran adalah cara yang digunakan oleh guru untuk melaksanakan proses belajar mengajar dan mencapai tujuan pembelajaran secara efektif yang ditetapkan dalam RPP sehingga pembelajaran menjadi aktif, kreatif, dan menyenangkan.

Salah satu metode pembelajaran yang cukup dikenal adalah metode demonstrasi. Menurut pendapat Djamarah metode demonstrasi adalah cara penyajian pelajaran dengan meragakan atau mempertunjukkan kepada peserta didik suatu proses, situasi atau benda tertentu yang sedang dipelajari, baik sebenarnya ataupun tiruan, yang sering disertai dengan penjelasan lisan. Dengan metode demonstrasi, proses penerimaan siswa terhadap pelajaran akan lebih berkesan secara mendalam, sehingga membentuk pengertian dengan baik dan sempurna. Juga peserta didik dapat mengamati dan memperhatikan apa yang diperlihatkan selama pelajaran berlangsung. Metode demonstrasi memiliki kelebihan dan kekurangan, sebagai berikut:

Kelebihan metode demonstrasi, antara lain:

1) Dapat membuat pengajaran menjadi lebih jelas dan lebih konkret, sehingga menghindari verbalisme (pemahaman secara kata-kata atau kalimat).

2) Siswa lebih mudah memahami apa yang dipelajari.

3) Proses pengajaran lebih menarik.

4) Siswa dirangsang untuk aktif mengamati, menyesuaikan antara teori dengan kenyataan, dan mencoba melakukannya sendiri.

Kekurangan metode demonstrasi, antara lain:

1) Metode ini memerlukan keterampilan guru secara khusus, karena tanpa ditunjang dengan hal itu, pelaksanaan demonstrasi akan tidak efektif.

2) Fasilitas seperti peralatan, tempat, dan biaya yang memadai tidak selalu tersedia dengan baik. 
3) Demonstrasi memerlukan kesiapan dan perencanaan yang matang di samping memerlukan waktu yang cukup panjang, yang mungkin terpaksa mengambil waktu atau jam pelajaran lain [21]

Teori di atas didukung oleh Anitah dan sulfemi bahwa metode demonstrasi merupakan metode mengajar yang menyajikan bahan pelajaran dengan mempertunjukkan secara langsung objek atau cara melakukan sesuatu sehingga dapat mempelajarinya secara proses. Demonstrasi dapat digunakan pada semua mata pelajaran yang akan dicapainya. Salah satu yang perlu diperhatikan dalam pelaksanaan demonstrasi adalah posisi peserta didik seluruhnya harus dapat memperhatikan (mengamati) objek yang akan didemonstrasikan. Selama proses demonstrasi, guru sudah mempersiapkan alatalat yang akan digunakan dalam demonstrasi tersebut [9] .[23]

Langkah-langkah metode demonstrasi yang harus dilakukan dalam pembelajaran adalah sebagai berikut.

1) Mempersiapkan alat bantu yang akan digunakan dalam pembelajaran.

2) Memberikan penjelasan tentang topik yang akan didemonstrasikan.

3) Pelaksanaan demonstrasi bersamaan dengan perhatian dan peniruan dari peserta didik.

4) Penguatan (diskusi, tanya jawab, dan/atau latihan) terhadap hasil demonstrasi.

5) Kesimpulan [24]

Guru dituntut menguasai bahan pelajaran serta mampu mengorganisasi kelas. Sering terjadi kesalahan dalam pelaksanaan demonstrasi guru, bahkan posisi pandang siswa tidak fokus terhadap objek yang ditampilkan guru. Demonstrasi digunakan semata-mata hanya untuk; (1) mengonkretkan sesuatu konsep atau prosedur yang abstrak; (2) mengajarkan bagaimana berbuat atau menggunakan prosedur secara tepat; (3) meyakinkan bahwa alat dan prosedur tersebut bisa digunakan; (4) membangkitkan minat menggunakan alat dan prosedur [25]

Kemudian Winataputra berpandangan, metode demonstrasi merupakan metode mengajar yang menyajikan bahan pelajaran dengan mempertunjukan 
secara langsung objeknya atau caranya melakukan sesuatu untuk mempertunjukan proses tertentu. Metode demonstrasi dapat menggiring peserta didik ke dalam proses pembelajaran aktif, kreatif, efektif, dan menyenangkan (PAKEM) yang sangat dianjurkan untuk digunakan dalam proses pembelajaran modern di era globalisasi seperti sekarang ini.

Berdasarkan uraian di atas dapat disimpulkan bahwa metode demonstrasi adalah cara mengajar yang dilakukan guru dengan menyajikan bahan pelajaran dengan mempertunjukkan secara langsung objek yang ditampilkan guru untuk membangkitkan minat belajar peserta didik dan menggiring peserta didik ke dalam proses pembelajaran aktif, kreatif, efektif, dan menyenangkan.

\section{Media Audiovisual}

Asal kata media yaitu dari bahasa Latin, medius yang berarti “tengah/perantara/pengantar". Gerlach dan Ely dalam Arsyad mengatakan bahwa media apabila dipahami secara garis besar adalah manusia, materi, atau kejadian yang membangun kondisi yang membuat peserta didik mampu memperoleh pengetahuan, keterampilan, dan sikap. Dalam pengertian ini, guru, buku teks, dan lingkungan sekolah merupakan media. Secara lebih khusus, pengertian media dalam proses pembelajaran cenderung diartikan sebagai alatalat grafis, photografis, elektronis untuk menangkap, memproses, dan menyusun kembali informasi visual atau verbal.[26]

Media pembelajaran sering disebut alat bantu atau media komunikasi seperti yang dikemukakan oleh Hamalik dalam Arsyad di mana melihat hubungan komunikasi akan berjalan lancar dengan hasil yang maksimal apabila menggunakan alat bantu. Sementara Gagne dan Briggs dalam Arsyad secara implisit mengatakan bahwa media pembelajaran meliputi alat yang secara fisik digunakan untuk menyampaikan isi materi pengajaran, yang terdiri dari buku, tape recorder, kaset, video recorder, film, slide, foto, gambar, grafik, televisi, dan komputer. [28] Dengan kata lain, media adalah komponen sumber belajar atau wahana fisik yang mengandung materi instruksional di lingkungan peserta didik yang dapat merangsang peserta didik untuk belajar [27]. Kemudian National education association memberi definisi media sebagai bentuk-bentuk komunikasi baik tercetak maupun audio-visual dan peralatannya, dengan demikian media 
dapat dibuat, dilihat, didengar, atau dibaca. Sama seperti pendapat Briggs dalam Peletai dan sulfemi bahwa media pembelajaran adalah sarana fisik untuk menyampaikan isi atau materi pembelajaran seperti buku, film, video, slide.[28]

Teori-teori di atas pun senada dengan pandangan Djamarah yang menguraikan ciri-ciri umum dari media pembelajaran, antara lain:

1) Media pembelajaran identik artinya dengan pengertian keperagaan yang berasal dari kata "raga", artinya suatu benda yang dapat diraba, dilihat, didengar, dan yang diamati melalui pancaindera manusia.

2) Ditekankan di benda atau hal-hal yang bisa dilihat dan didengar.

3) Media pembelajaran digunakan dalam rangka hubungan (komunikasi) dalam pembelajaran, antara guru dan peserta didik.

4) Media pembelajaran adalah semacam alat bantu belajar mengajar di kelas maupun di luar kelas.

5) Media nama lainnya adalah "perantara" (medium, media) dan digunakan dalam rangka pendidikan.

6) Media pembelajaran mengandung aspek sebagai alat dan teknik yang sangat relevan metode pembelajaran [21] .[29]

Menurutnya, yang dimaksud dengan media pembelajaran adalah alat, metode, dan teknik yang digunakan dalam rangka lebih mengefektifkan komunikasi dan interaksi antara pendidik dan peserta didik dalam proses pembelajaran di sekolah.

Berdasarkan uraian di atas penulis menyimpulkan bahwa media pembelajaran merupakan alat bantu yang sangat berguna dalam kegiatan pembelajaran/materi instruksional, yakni dapat mewakili sesuatu yang tidak dapat disampaikan guru secara verbal. Keefektifan daya serap peserta didik akan pelajaran yang sulit dapat terjadi dengan bantuan alat bantu.

Menurut Anitah Media audiovisual merupakan kombinasi antara audio dan visual atau biasa disebut media pandang dengar. Sudah barang tentu apabila anda menggunakan media ini akan semakin lengkap dan optimal penyajian bahan ajar terhadap para siswa, selain dari itu media ini dalam batasbatas tertentu dapat juga menggantikan peran dan tugas guru. Dalam hal ini, guru tidak selalu berperan sebagai penyaji materi (teacher), tetapi penyajian 
materi bisa diganti oleh media audiovisual maka peran guru bisa beralih menjadi fasilitator belajar, yaitu memberikan kemudahan bagi para siswa untuk belajar [9]

Menurut Djamarah media audiovisual adalah media yang mempunyai unsur suara dan unsur gambar. Media ini mempunyai kemampuan yang baik yaitu mengandalkan kemampuan suara dan kemampuan indera penglihatan.

Hal-hal positif dalam penggunaan audiovisual, yaitu:

1) Dapat menarik perhatian untuk periode-periode yang singkat dari rangsangan luar lainnya.

2) Dengan alat perekam video sejumlah besar penonton dapat memperoleh informasi dari ahli-ahli / spesialis.

3) Demonstrasi yang sulit dapat dipersiapkan dan direkam sebelumnya, sehingga pada waktu mengajar guru bisa memusatkan perhatian peserta didik pada penyajiannya.

4) Menghemat waktu dan rekaman dapat diputar berulang-ulang.

5) Rekaman bisa diamati lebih dekat dengan model, model seperti objek yang terlalu besar, terlalu jauh, terlalu kecil, terlalu mahal, terlalu langka, atau terlalu rumit.

6) Keras lemah suara yang bisa diatur dan disesuaikan bila akan disisipi komentar yang akan didengar.

7) Gambar proyeksi bisa di-“beku”-kan atau berhenti sejenak untuk diamati dengan seksama. Guru bisa mengatur di mana dia akan menghentikan gerakan gambar tersebut [21]

Sementara menurut Wibawa Media audiovisual yaitu media yang dapat dilihat sekaligus dapat didengar seperti film bersuara, video, televisi, dan sound slide. [30] Dengan karakteristik yang lebih lengkap, media audiovisual memiliki kemampuan untuk dapat mengatasi kekurangan dari media audio atau media visual saja. Media audiovisual ini lebih realistis. Ditinjau dari karakteristiknya, media audiovisual pada dasarnya dapat dibedakan menjadi dua, yaitu: (1) Media audiovisual diam, contohnya yaitu: film strip bersuara, slide bersuara, komik dengan suara, dll; (2) Media audiovisual gerak, contohnya yaitu: televisi, video, film, dll. [31] 
Media audiovisual merupakan media pembelajaran tampak dengar yang dapat digunakan untuk menyampaikan pesan-pesan/materi pelajaran. Dikatakan tampak dengar karena unsur dengar dan unsur penglihatan dapat disajikan serentak. Dengan kata lain media audiovisual adalah rangkaian gambar elektronik yang disertai unsur audio yang dituangkan pada pita video, dan dapat dilihat melalui alat pemutar video player dan jika dalam bentuk VCD maka menggunakan VCD player yang dihubungkan ke monitor televisi. Media audiovisual memiliki karakteristik yang dimilikinya baik itu kelebihan maupun kekurangannya Siddiq Kelebihan media pembelajaran audiovisual antara lain:

1) Merupakan media gerak perpaduan gambar dan suara;

2) Mampu mempengaruhi tingkah laku manusia melebihi media cetak;

3) Dapat digunakan seketika. Dapat digunakan secara berulang;

4) Dapat menyajikan materi yang secara fisik tidak dapat dibawa ke kelas;

5) Dapat menyajikan objek secara detail;

6) Tidak memerlukan ruang gelap;

7) Dapat menyajikan objek yang berbahaya;

8) Dapat diperlambat atau dipercepat;

9) Dapat digunakan untuk klasikal atau pun individual[31]

Media pembelajaran audiovisual di samping memiliki kelebihan yang banyak juga memiliki keterbatasan. Keterbatasan yang dimiliki bahan belajar audio visual antara lain:

1) Memerlukan dana yang relatif banyak/mahal;

2) Memerlukan keahlian khusus;

3) Sukar untuk direvisi

4) Memerlukan arus listrik.[32]

Maka penulis menyimpulkan media pembelajaran audiovisual adalah alat komunikasi dalam kegiatan pembelajaran yang mentransfer materi instruksional berbentuk gambar sekaligus suara yang dapat dilihat dan didengar seperti film bersuara, video, televisi, dan sound slide.

\section{Pelaksanaan Pembelajaran}


Sebelum melakukan pembelajaran dilaksanakan, terlebih dahulu disusun berbagai instrumen yang akan digunakan untuk mengumpulkan data dalam pelaksanaan penelitian tindakan kelas. Kemudian, menyusun rencana perbaikan pembelajaran yang akan digunakan dalam penelitian tindakan kelas dengan terlebih dahulu menentukan Kompetensi Dasar mata pelajaran IPS yaitu mendeskripsikan kenampakan alam di lingkungan kabupaten/kota dan provinsi serta hubungannya dengan keragaman sosial budaya.

Berikut kegiatan pembelajaran yang dilaksanakan

a. Perencanaan

Dalam pembelajarn terlebih dahulu membuat rencana perbaikan pembelajaran berdasarkan refleksi untuk mencapai tujuan pembelajaran yang lebih baik. Hal-hal yang dipersiapkan adalah menyusun perangkat pembelajaran yang lebih lengkap sesuai dengan tujuan yang ingin dicapai, dan membuat lembar observasi untuk mengamati partisipasi aktif siswa dalam pembelajaran.

b. Pelaksanaan

1) Kegiatan awal

Pra Pembelajaran

a) Guru mengondisikan peserta didik ke dalam situasi belajar yang kondusif, membentuk kelompok masing-masing 5-6 orang.

b) Guru menyiapkan media audio visual sebagai media pembelajaran.

Apersepsi

a) Guru mengajak peserta didik berdoa.

b) Guru menanyakan kabar peserta didik dan mengabsen kehadiran peserta didik.

c) Guru memberikan motivasi belajar kepada para peserta didik melalui lagu "Menanam Jagung".

d) Guru mengajukan pertanyaan sebagai berikut.

i) Dimanakah tempat yang tepat untuk bercocok tanam tanaman jagung?

ii) Tanaman apa saja yang tepat dikembangbiakan di dataran rendah seperti di lingkungan sekitar tempat tinggal kita? 
e) Guru menyampaikan tujuan pembelajaran.

2) Kegiatan inti

a) Eksplorasi

i) Guru menjelaskan materi pembelajaran yaitu IPS tentang materi kenampakan alam di depan kelas.

ii) Guru mendemonstrasikan bentuk kenampakan alam dengan media pembelajaran audio visual.

iii) Guru dan peserta didik bertanya jawab tentang materi kenampakan alam.

b) Elaborasi

i) Ketua kelompok diskusi maju ke depan untuk mencoba mengisi teka teki silang (TTS) tentang materi kenampakan alam.

ii) Peserta didik mengisi lembar kerja kegiatan IPS tentang materi kenampakan alam berbentuk TTS secara berdiskusi kelompok.

c) Konfirmasi

i) Guru bertanya jawab tentang hal-hal yang belum diketahui peserta didik yang berkaitan dengan materi pembelajaran.

ii) Guru bersama siswa bertanya jawab meluruskan kesalahan pemahaman, memberikan penguatan dan penyimpulan tentang kenampakan alam.

3) Kegiatan Akhir

a) Peserta didik diberi kesempatan untuk bertanya hal-hal yang belum jelas (keberanian).

b) Peserta didik dengan bimbingan guru menyimpulkan materi yang telah dibahas.

c) Peserta didik mengerjakan evaluasi (kejujuran).

d) Penilaian hasil evaluasi.

e) Pemberian umpan balik.

f) Guru menutup pelajaran dengan mengucapkan salam.

Peneliti melakukan pengamatan terhadap aktifitas peserta didik dalam mengikuti perbaikan pembelajaran dengan metode demonstrasi dan 
penggunaan media pembelajaran audiovisual. Hasil penelitian ternyata hasil belajar peserta didik materi kenampakan alam meningkat.

Pada pembelajaran ini beberapa hasil belajar peserta didik, yaitu:

1. Dalam menyampaikan pembelajaran peneliti menggunakan metode demonstrasi dengan media audio visual sehingga menarik bagi peserta didik, peserta didik mudah memahami dan mengerti.

2. Memberikan motivasi serta reward kepada seluruh peserta didik.

3. Melibatkan seluruh peserta didik dalam proses pembelajaran.

4. Dalam menjelaskan materi secara perlahan-lahan sehingga oleh semua peserta didik dapat memahami.

5. Interaksi antara saya dan peserta didik harus lebih dikembangkan lagi.

Dalam kegiatan pembelajaran ini peserta didik sangat berminat dan termotivasi untuk mengikuti pelajaran IPS. Ini disebabkan karena tersedianya media yang tepat dan sesuai dengan materi yang diajarkan oleh guru selama proses belajar mengajar berlangsung, sehingga tercipta suasana pembelajaran yang menantang, merangsang dan menyenangkan bagi peserta didik. Dengan hasil siklus 2 ini penulis tidak melanjutkan kepenelitian ke siklus berikutnya.

Peran guru tidak kalah pentingnya dalam menggerakan minat belajar peserta didik. Salah satu yang digunakan yaitu dengan menyediakan sumber dan media pembelajaran yang tepat dan sesuai serta melibatkan peserta didik dalam proses pembelajaran berlangsung. Mengenal dan sanggup menggunakan metode mengajar kemampuan dasar guru yang paling utama dalam meraih sukses di sekolah. Guru yang tidak mengenal metode mengajar jangan diharapkan bisa melaksanakan tugas mengajar dengan baik, sebaik-baiknya penguasaan materi menjadi landasan pokok seorang guru untuk memiliki kemampuan mengajar dan menguasai materi dengan baik senantiasa mencoba berbagai metode untuk diterapkan sesuai dengan perkembangan situasi di kelas dan tidak terlalu terikat dengan patokan persiapan mengajar dalam menguasai betul materi ajar yang lebih kreatif dan inovatif dalam menyampaikan materi ajarnya, dengan melakukan materi ajar yang kreatif dan inovatif maka akan mendapatkan hasil pembelajaran yang baik, para peserta didik pada tingkat 
kelas rendah pun dalam pelaksanaan kegiatan pembelajaran perlu membuat kondisi kelas yang menyenangkan dan tidak membosankan karena apabila para peserta didik dalam selama proses pembelajaran membosankan akan mendapatkan hasil yang tidak sesuai dengan yang diinginkan [33]. Dengan demikian, pembelajaran menggunakan metode demonstrasi dengan media audio visual dapat meningkatkan hasil belajar, keaktifan serta motivasi peserta didik. Materi yang disampaikan oleh guru dapat dimengerti oleh peserta didik. Tanggung jawa peserta didik terhadap tugas cukup tinggi, serta membantu peserta didik untuk terlibat aktif dalam kegiatan pembelajaran.

\section{KESIMPULAN DAN SARAN}

Berdasarkan hasil penelitian perbaikan pembelajaran yang telah dilaksanakan mulai dari prasiklus, siklus 1 sampai dengan siklus 2 pada mata pelajaran IPS, maka penulis dapat menarik kesimpulan sebagai berikut: 1) Dengan demikian pembelajaran menggunakan metode demonstrasi dengan media audio visual dapat meningkatkan hasil belajar, keaktifan serta motivasi bagi peserta didik. Materi yang disampaikan oleh guru dapat dimengerti oleh peserta didik. 2) Tanggung jawab peserta didik terhadap tugas cukup tinggi, serta membantu peserta didik terlibat aktif di dalam kegiatan pembelajaran.

Berdasarkan kesimpulan di atas, ada beberapa hal yang sebaiknya dilakukan oleh guru dalam rangka meningkatkan hasil belajar peserta didik antara lain: 1) Dengan perbaikan pembelajaran melalui Penelitian Tindakan Kelas hendaknya guru termotifasi untuk mempersiapkan pembelajaran yang lebih baik. 2) Guru membiasakan menganalisis hasil belajar peserta didik secara terus-menerus, berkala, terprogram, dan berkesinambungan. 3) Guru hendaknya mampu menyajikan materi pelajaran IPS dengan metode demonstrasi, sehingga kemampuam peserta didik dapat terus meningkat. 4) Perbaikan pembelajaran melalui penelitian tindakan kelas memberi kontribusi dan manfaat bagi perbaikan proses pembelajaran.

\section{Daftar Pustaka}


[1] Sulfemi, W. B., \& Kamalia, Y. (2020). Jigsaw Cooperative Learning Model Using Audiovisual Media To Improve Learning Outcomes. JPsd (Jurnal Pendidikan Sekolah Dasar). 6 (1), 30-42. DOI: http://dx.doi.org/10.30870/jpsd.v6i1.4919

[2] Arsyad, Arsyad dan Sulfemi, Wahyu Bagja. (2018) Metode Role Playing Berbantu Media Audio Visual Pendidikan dalam Meningkatkan Belajar IPS. Jurnal Pendidikan Ilmu Pengetabuan Sosial Indonesia. 3 (2). 41 - 46. DOI: http://dx.doi.org/10.26737/jpipsi.v3i2.1012

[3] Damanhuri, Zerri., Rahman, Hakim., Mega, Utami Pratiwi. (2016). Penerapan Model Pembelajaran Inquiri Terhadap Hasil Belajar Siswa Sekolah Dasar Pada Mata Pelajaran IPS. JPSD Vol. 2 No. 2. 156-165

[4] Sulfemi, Wahyu Bagja., \& Desmiati, Z. (2018). Model Pembelajaran Missouri Mathematics Project Berbantu Media Relief Experience dalam Meningkatkan Hasil Belajar Siswa. PENDAS MAHAKAM: Jurnal Pendidikan Dasar, 3(3), 232-245. https://jurnal.fkipuwgm.ac.id/index.php/pendasmahakam/article/view/269/173

[5] Windiyani, Tustiyana Lina Novita, Anisa Permatasari. 2018. Penggunaan Media Pembelajaran Gambar Fotografi Pada Mata Pelajaran Ilmu Pengetahuan Sosial Siswa Sekolah Dasar. Jurnal JPSD Untirta. 4 (1). 91101

[6] Sulfemi, Wahyu Bagja. (2018). Manajemen Kurikulum di Sekolah. Bogor : Visi Nusantara Maju

[7] Saifuddin Azmar, (2001). Metode Penelitian, Yogyakarta: Pustaka Pelajar.hal. 5.

[8] Sulfemi, Wahyu Bagja. (2018). Modul Manajemen Pendidikan Non Formal. Bogor: STKIP Muhammadiyah Bogor

[9] Anitah, Sri. dkk. (2014). Strategi Pembelajaran di SD. Banten: Universitas Terbuka.

[10] Hamalik, Oemar. (2005). Proses Belajar Mengajar. Jakarta: PT Bumi Aksara.

[11] Sulfemi, W. B., \& Yuliana, D. (2019). Penerapan Model Pembelajaran Discovery Learning Meningkatkan Motivasi Dan Hasil Belajar Pendidikan Kewarganegaraan. Jurnal Rontal Keilmuan Pancasila dan Kewarganegaraan, 5(1), 17-30. Doi: http://dx.doi.org/10.29100/jr.v5i1.1021.

[12] Sulfemi, Wahyu Bagja. (2019). Manajemen Pendidikan Berbasis Multi Budaya. Bogor : STKIP Muhammadiyah Bogor.

[13] Sulfemi, W. B., \& Minati, H. (2018). Meningkatkan Hasil Belajar Peserta Didik Kelas 3 SD Menggunakan Model Picture And Picture dan Media $\begin{array}{lllll}\text { Gambar } & \text { Seri. } & \text { JPSD. } & 4 & \text { (2), } 228-\end{array}$ DOI: http://dx.doi.org/10.30870/jpsd.v4i2.3857 
[14] Sudjana, Nana. (2014). Penilaian Hasil Proses Belajar Mengajar. Jawa Barat: Remaja Rosda Karya.

[15] Sulfemi, Wahyu Bagja dan Yuliani, Nunung. (2019). Model Pembelajaran Contextual Teaching And Learning (CTL) Berbantu Media Miniatur Lingkungan Untuk Meningkatkan Hasil Belajar IPS. Edunomic. 7 (2). 73 84. DOI : $10.33603 /$ ejpe.v7i2.1970

[16] Sardjiyo. dkk. (2014). Pendidikan IPS di SD. Banten: Universitas Terbuka.

[17] Sulfemi, W. B., \& Mayasari, N. (2019). Peranan Model Pembelajaran Value Clarification Technique Berbantuan Media Audio Visual Untuk Meningkatkan Hasil Belajar IPS. Jurnal Pendidikan. 20 (1). 53-68. DOI: https://doi.org/10.33830/jp.v20i1.235.2019

[18] Ahmadi, H. Abu. (2009). Ilmu Sosial Dasar. Jakarta: PT Rineka Cipta.

[19] Sulfemi, Wahyu Bagja dan Setianingsih. (2018), Penggunaan Tames Games Tournament (TGT) Dengan Media Kartu Dalam Meningkatkan Hasil Belajar. Journal of Komodo Science Education (JKSE). 1 (1), 1-14. https://www.ejournal.stkipsantupaulus.ac.id/index.php/jkse/article/vie w/191/180

[20] Rachmawati, Tutik. (2015). Teori Belajar dan Proses Pembelajaran yang Mendidik. Yogyakarta: Gava Media.

[21] Djamarah, Syaiful Bahri. (2006). Strategi Belajar Mengajar. Jakarta: PT Rineka Cipta.

[22] Nurhayati. dkk. (2015). Perencanaan dan Pengajaran Bahasa Inggris. Jakarta: Universitas Indraprasta PGRI.

[23] Sulfemi, Wahyu Bagja., \& Desmiati, Z. (2018). Model Pembelajaran Missouri Mathematics Project Berbantu Media Relief Experience dalam Meningkatkan Hasil Belajar Siswa. PENDAS MAHAKAM: Jurnal Pendidikan Dasar, 3(3), 232-245. https://jurnal.fkipuwgm.ac.id/index.php/pendasmahakam/article/view/269/173

[24] Sulfemi, Wahyu Bagja dan Nurhasanah. (2018). Penggunaan Metode Demontrasi dan Media Audio Visual Dalam Meningkatkan Hasil Belajar Peserta Didik Mata Pelajaran IPS. Jurnal Pendas Mabakam. 3 (2). 151-158. https://jurnal.fkipuwgm.ac.id/index.php/pendasmahakam/article/view $/ 229$

[25] Sulfemi, Wahyu Bagja dan Supriyadi, Dede. (2018). Pengaruh Kemampuan Pedagogik Guru dengan Hasil Belajar IPS. Edutecno 17 (1), $1-10$

[26] Sulfemi, Wahyu Bagja. (2018). Hubungan Motivasi Belajar Dengan Hasil Belajar IPS Di SMP Kabupaten Bogor. Edutecno 18 (2), 1-8.

[27] Arsyad, Azhar. (2014). Media Pembelajaran. Jakarta: Rajawali Pers.

[28] Palettei, A. D., \& Sulfemi, Sulfemi, W. B. (2019). Pengaruh Kelompok Kerja Guru (KKG) Terhadap Peningkatan Kompetensi Pedagogik dan 
Kemampuan Menulis Karya Ilmiah. Jurnal Pendidikan Dasar Indonesia Jurnal Pendidikan Dasar Indonesia (JPDI). 7 (2). 53 - 58. DOI: http://dx.doi.org/10.26737/jpdi.v4i2.1522.

[29] Sulfemi, Wahyu Bagja. (2017). Analisis Pengaruh Motivasi Dan Disiplin Terhadap Kinerja Guru (Studi Kasus di SMA Negeri 1 Pamijahan Kabupaten Kabupaten Bogor). Prosiding Seminar Nasonal STKIP Mubammadiyah Bogor. 1 (1), 342-357

[30] Wibawa, Basuki. dkk. (1992). Media Pengajaran. Jakarta: Depdikbud.

[31] Sulfemi, Wahyu Bagja dan Abdul Qodir. (2017). Hubungan Kurikulum 2013 Dengan Motivasi Belajar Peserta Didik Di SMK Pelita Ciampea. Edutecno 17 (2), 1-8.

[32] Sulfemi, Wahyu Bagja. (2019). Model Pembelajaran Kooperatif Mind Mapping Berbantu Audio Visual Dalam Meningkatkan Minat, Motivasi dan Hasil Belajar IPS. Jurnal PIPSI (Jurnal Pendidikan IPS Indonesia), 4(1), 13-19. DOI: http://dx.doi.org/10.26737/jipips.v4i1.1204

[33] Sulfemi, Wahyu Bagja dan Lestari, Ayu Hopilatul. (2017). Korelasi Kompetensi Pedagogik Guru dengan Prestasi Belajar Mata Pelajaran IPS Di SMP Muhammadiyah Pamijahan Kabupaten Bogor. Edutecno. 16 (1), $1-16$ 